\title{
IDENTIFICATION OF NOVEL 5-STYRYL-1,2,4-OXADIAZOLE/TRIAZOLE DERIVATIVES AS THE POTENTIAL ANTI-ANDROGENS THROUGH MOLECULAR DOCKING STUDY
}

\author{
PARANJEET KAUR, GOPAL L. KHATIK \\ Lovely Professional University, Jalandhar-Delhi G. T. Road (NH-1), Phagwara, Punjab (India) \\ Email: gopal_niper@rediffmail.com
}

Received: 04 Jul 2016 Revised and Accepted: 12 Aug 2016

ABSTRACT

Objective: To identify the novel and simple bioactive antiandrogens, that can overcome to side effects as well as drug resistance.

Methods: The AutoDock Vina (ADT) 1.5.6 software is used for molecular docking purposes. The molecular structures were drawn in ChemBiodraw ultra and by the help of ChemBiodraw 3D, all structures were energy minimized by MM2 method and converted to pdb extension file which is readable at the $\mathrm{ADT}$ interface.

Results: Total ten compounds from both series were shown better binding affinity than $R$-bicalutamide including oxadiazole and triazole series. Among these pk42 and pk46 were studied in-depth which showed best binding affinity to the androgen receptor. The cis-isomers were found better than their trans-isomer.

Conclusion: Novel 5-styryl-1,2,4-oxadiazole/triazole derivatives were studied through molecular modeling using Autodock Vina. The potent compounds which showed better binding affinity than $R$-bicalutamide like pk24 and 46 were further analyzed for their interactions. The conformational effect also found significant in binding to the androgen receptor.

Keywords: Antiandrogen, Oxadiazole, Triazole, Autodock Vina, Molecular docking, Prostate cancer

(c) 2016 The Authors. Published by Innovare Academic Sciences Pvt Ltd. This is an open access article under the CC BY license (http://creativecommons. org/licenses/by/4. 0/) DOI: http://dx.doi.org/10.22159/ijpps.2016v8i10.13844

\section{INTRODUCTION}

Prostate cancer is one of the major concerns worldwide as it has emerged as the second leading cause of cancer-related deaths in men [1] More than 6,70,000 men are diagnosed with prostate cancer every year. In 2013 in the United States, 233,000 newer cases of cancer were found and 29,480 deaths were reported [2,3]. Although PC incidence rates are lower in Asian countries but in India, it has increased recently [4]. Testosterone and dihydrotestosterone are the two steroidal androgenic hormones which act as the main facilitators for the progression and development of the prostate cancer [5]. Androgens upon binding to the androgen receptor (AR) cause conformational changes in the AR genes. These AR-regulated genes encode prostate-specific antigen (PSA), is a serine protease, which acts as an important biomarker for the pathogenesis of PCa [6-8]. Hence steroidal agents like cyproterone acetate and spironolactone were employed for the treatment of prostate cancer (fig. 1) [9-11]

But this therapy failed due to several drawbacks attributed to the non-specific effects of steroidal antiandrogens such as crossreactivity, poor bioavailability and lack of tissue selectivity, etc. these limitations has shifted the focus of researchers towards nonsteroidal class of anti-androgens as a potential of diminishing the cross reactions with other steroidal hormones which eliminates the unwanted side effects [12]. Another important application of nonsteroidal antiandrogens is their potential to provide various structural modifications to afford more potent scaffolds. Although this approach initially shows an $80-90 \%$ response rate, but when treatment is continued for $1-2 \mathrm{y}$, approximately $50 \%$ of patients progress to fatal androgen independent disease [13-41].

Clearly, there is an unmet medical need for the treatment of advanced $\mathrm{CaP}$. For this reason, efforts have been devoted to identifying novel small-molecule antagonists of the AR that are more effective than the current therapies which led to the newer classes of non-steroidal compounds which showed more potent activity as compared to the marketed non-steroidal anti-prostate drugs.

However, these newer discoveries in the class of non-steroidal AR ligands provide the new insights to achieve the specificity and selectivity in tissue targeting as selective androgen receptor modulators (SARMs)

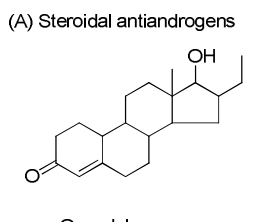

Oxendolone

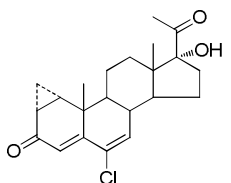

Cyproterone

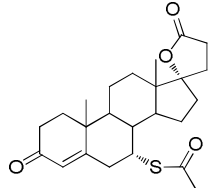

Spironolactone

(B) Non-steroidal antiandrogens

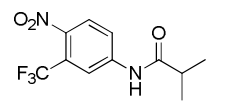

Flutamide<smiles>CC1(C)NC(=O)N(c2ccc([N+](=O)[O-])c(C(F)(F)F)c2)C1=O</smiles>

Nilutamide

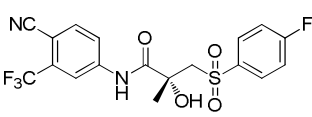

(R)-Bicalutamide

Fig. 1: Antiandrogen ligands 
Recently 3-aryl-6-methyl-2-thioxotetrahydropyrimidin-4(1H)-ones were reported as anti-prostate cancer agents, selectively inhibiting the androgen receptor [42-45]. Our interest and research works on biologically active heterocyclic scaffolds resulted in identifying a new class of antagonists based on 1,2,4-oxadiazole [43]; their stereo chemical aspects and preliminary virtual screening results are discussed herein. The target molecules were designed on the basis of molecular modeling, considering the structures of $R$-bicalutamide as a gold standard non-steroidal anti-prostate cancer agent.

\section{MATERIALS AND METHODS}

Molecular modeling is a well-explored tool for identification of potent compound without investing too much effort and money in research [46-50]. For molecular docking purpose we have used the AutoDock Vina (ADT) 1.5.6 software [51] and for comparison, the outcomes is compared in binding affinity score for best-docked conformation. The molecular structures were drawn in ChemBiodraw ultra and by the help of ChemBiodraw 3D, all structures were energy minimized by MM2 method [52] and converted to pdb extension file which is readable at the ADT interface. To identify the potential antiandrogen, we have used the $1 Z 95 \mathrm{pdb}$ file downloaded from pdb data bank (http://www. rcsb. org/pdb/explore. do?pdbId=1z95). The outcomes of results were analyzed by AutoDock Vina result which reveals close contact, hydrogen bond, hydrophilic and hydrophobic interactions.

\section{RESULTS AND DISCUSSION}

The X-ray crystal structure of $R$-Bicalutamide in WL AR LBD complex revealed that it oriented at the active binding site in a bent conformation, due to hydrogen bonding interactions of chiral hydroxyl with amide nitrogen (fig. 2). Therefore, we assumed that conformationally restricted model with relevance to anti-prostate activity can be investigated. With our current interests on heterocyclic scaffolds and anti-prostate cancer agents, we designed conformationally restricted oxadiazole derivatives with bioisosteric replacement with $\mathrm{Cl}, \mathrm{CN}, \mathrm{CF}_{3}, \mathrm{~F}, \mathrm{NO}_{2}, \mathrm{Br}[37,38]$.
The restricted conformation further strengthens with a double bond at ring $\mathrm{B}$ in the newly designed pharmacophore (fig. 2). Total 160 compounds were designed and studied by molecular docking through software Autodock Vina. The designed compounds were drawn in 3D structure by using ChemBioDraw Ultra 12.0 (Cambridge Soft) and geometry was minimized by using MM2 (molecular mechanics method).

All geometries minimized structures were then converted or transformed into a readable format (pdb) by ChemBioDraw Ultra and used in Autodock-vina software (ADT). The protein 1 Z95 (androgen receptor) is prepared by ADT through removing water molecules, repairing for missing atoms, adding polar hydrogen atoms only, adding Kollman charges, and saved as macromolecule 1Z95. The validation of method is performed by extracting the ligand present in the protein viz $R$-bicalutamide and docked which showed similar interaction as reported by Dalton et al. $[23,24]$. The results obtained from molecular docking of designed ligands on the validated protein 1295 and are summarized in table 1 for oxadiazoles and in table 2 for triazoles derivative. Here the binding affinity of ligand towards mutant androgen receptor is represented in terms of docking score.
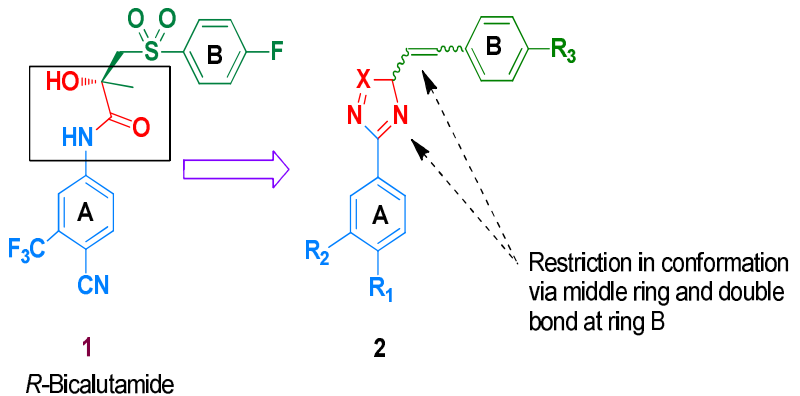

Fig. 2: Design of novel series of compounds based on $\boldsymbol{R}$ bicalutamide

Table 1: Designed ligands of oxadiazole derivatives (Series 1)

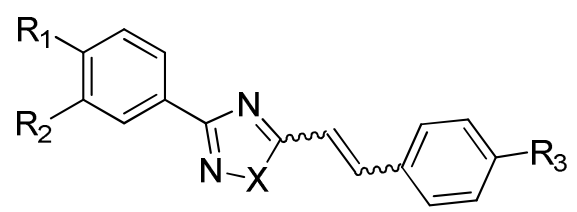

\begin{tabular}{|c|c|c|c|c|c|c|c|c|}
\hline \multirow[t]{2}{*}{ Entry } & \multirow{2}{*}{$\begin{array}{l}\text { Code } \\
\text { cis }\end{array}$} & \multirow{2}{*}{ Trans } & \multirow[t]{2}{*}{$\mathbf{R}_{\mathbf{1}}$} & \multirow[t]{2}{*}{$\mathbf{R}_{2}$} & \multirow[t]{2}{*}{$\mathbf{X}$} & \multirow[t]{2}{*}{$\mathbf{R}_{3}$} & \multicolumn{2}{|c|}{ Binding affinity (Kcal/mol) } \\
\hline & & & & & & & cis & Trans \\
\hline 1 & pk1 & pk81 & $\mathrm{H}$ & $\mathrm{H}$ & 0 & $\mathrm{H}$ & -9 & -8 \\
\hline 2 & pk2 & pk82 & $\mathrm{H}$ & $\mathrm{H}$ & 0 & $\mathrm{~F}$ & -9.3 & -8.1 \\
\hline 3 & pk3 & pk83 & $\mathrm{H}$ & $\mathrm{H}$ & 0 & $\mathrm{Cl}$ & -9.4 & -6.8 \\
\hline 4 & pk4 & pk84 & $\mathrm{H}$ & $\mathrm{H}$ & 0 & $\mathrm{Br}$ & $\mathrm{NA}^{*}$ & $\mathrm{NA}^{*}$ \\
\hline 5 & pk9 & pk89 & $\mathrm{F}$ & $\mathrm{Cl}$ & 0 & $\mathrm{H}$ & -9.8 & -8.5 \\
\hline 6 & pk10 & pk90 & $\mathrm{F}$ & $\mathrm{Cl}$ & 0 & $\mathrm{~F}$ & -10.1 & -7.9 \\
\hline 7 & pk11 & pk91 & $\mathrm{F}$ & $\mathrm{Cl}$ & 0 & $\mathrm{Cl}$ & -10.3 & -6.9 \\
\hline 8 & pk12 & pk92 & $\mathrm{F}$ & $\mathrm{Cl}$ & 0 & $\mathrm{Br}$ & $\mathrm{NA}^{*}$ & $\mathrm{NA}^{*}$ \\
\hline 9 & pk17 & pk101 & $\mathrm{Cl}$ & $\mathrm{F}$ & 0 & $\mathrm{H}$ & -9.6 & -8 \\
\hline 10 & pk18 & pk102 & $\mathrm{Cl}$ & $\mathrm{F}$ & 0 & $\mathrm{~F}$ & -10.1 & -7.1 \\
\hline 11 & pk19 & pk103 & $\mathrm{Cl}$ & $\mathrm{F}$ & 0 & $\mathrm{Cl}$ & -10 & -6.4 \\
\hline 12 & pk20 & pk104 & $\mathrm{Cl}$ & $\mathrm{F}$ & 0 & $\mathrm{Br}$ & $\mathrm{NA}^{*}$ & $\mathrm{NA}^{*}$ \\
\hline 13 & pk25 & pk105 & $\mathrm{Cl}$ & $\mathrm{CN}$ & 0 & $\mathrm{H}$ & -10.5 & -8.6 \\
\hline 14 & pk26 & pk106 & $\mathrm{Cl}$ & $\mathrm{CN}$ & 0 & $\mathrm{~F}$ & -10.9 & -7.8 \\
\hline 15 & pk27 & pk107 & $\mathrm{Cl}$ & $\mathrm{CN}$ & 0 & $\mathrm{Cl}$ & $\mathrm{NA}^{*}$ & -7 \\
\hline 16 & pk28 & pk108 & $\mathrm{Cl}$ & $\mathrm{CN}$ & 0 & $\mathrm{Br}$ & $\mathrm{NA}^{*}$ & $\mathrm{NA}^{*}$ \\
\hline 17 & pk33 & pk113 & $\mathrm{Cl}$ & $\mathrm{CF}_{3}$ & 0 & $\mathrm{H}$ & -10.4 & $\mathrm{NA}^{*}$ \\
\hline 18 & pk34 & pk114 & $\mathrm{Cl}$ & $\mathrm{CF}_{3}$ & 0 & $\mathrm{~F}$ & -11.1 & -7.8 \\
\hline 19 & pk35 & pk115 & $\mathrm{Cl}$ & $\mathrm{CF}_{3}$ & 0 & $\mathrm{Cl}$ & -10.9 & -7.3 \\
\hline 20 & pk36 & pk116 & $\mathrm{Cl}$ & $\mathrm{CF}_{3}$ & 0 & $\mathrm{Br}$ & $\mathrm{NA}^{*}$ & -8.3 \\
\hline 21 & pk41 & pk121 & $\mathrm{CN}$ & $\mathrm{CF}_{3}$ & 0 & $\mathrm{H}$ & -10.9 & -8.6 \\
\hline 22 & pk42 & pk122 & $\mathrm{CN}$ & $\mathrm{CF}_{3}$ & 0 & $\mathrm{~F}$ & -11.6 & -8.6 \\
\hline 23 & pk43 & pk123 & $\mathrm{CN}$ & $\mathrm{CF}_{3}$ & 0 & $\mathrm{Cl}$ & -11.5 & -7.6 \\
\hline 24 & pk44 & pk124 & $\mathrm{CN}$ & $\mathrm{CF}_{3}$ & 0 & $\mathrm{Br}$ & $\mathrm{NA}^{*}$ & $\mathrm{NA}^{*}$ \\
\hline 25 & pk49 & pk129 & $\mathrm{NO}_{2}$ & $\mathrm{CF}_{3}$ & 0 & $\mathrm{H}$ & -10.5 & -8.2 \\
\hline
\end{tabular}




\begin{tabular}{|c|c|c|c|c|c|c|c|c|}
\hline 26 & pk50 & pk130 & $\mathrm{NO}_{2}$ & $\mathrm{CF}_{3}$ & 0 & $\mathrm{~F}$ & -11.1 & -7 \\
\hline 27 & pk51 & pk131 & $\mathrm{NO}_{2}$ & $\mathrm{CF}_{3}$ & 0 & $\mathrm{Cl}$ & -10.7 & -6.1 \\
\hline 28 & pk52 & pk132 & $\mathrm{NO}_{2}$ & $\mathrm{CF}_{3}$ & 0 & $\mathrm{Br}$ & $\mathrm{NA}^{*}$ & NA* \\
\hline 29 & pk57 & pk137 & $\mathrm{NO}_{2}$ & $\mathrm{~F}$ & 0 & $\mathrm{H}$ & -9.8 & -7.6 \\
\hline 30 & pk58 & pk138 & $\mathrm{NO}_{2}$ & $\mathrm{~F}$ & 0 & $\mathrm{~F}$ & -10.3 & -6.7 \\
\hline 31 & pk59 & pk139 & $\mathrm{NO}_{2}$ & $\mathrm{~F}$ & 0 & $\mathrm{Cl}$ & -10.2 & -5.3 \\
\hline 32 & pk60 & pk140 & $\mathrm{NO}_{2}$ & $\mathrm{~F}$ & 0 & $\mathrm{Br}$ & $\mathrm{NA}^{*}$ & $\mathrm{NA}^{*}$ \\
\hline 33 & pk65 & pk145 & $\mathrm{CF}_{3}$ & $\mathrm{~F}$ & 0 & $\mathrm{H}$ & -10.2 & NA* \\
\hline 34 & pk66 & pk146 & $\mathrm{CF}_{3}$ & $\mathrm{~F}$ & 0 & $\mathrm{~F}$ & -10.4 & -6.4 \\
\hline 35 & pk67 & pk147 & $\mathrm{CF}_{3}$ & $\mathrm{~F}$ & 0 & $\mathrm{Cl}$ & -10.4 & -5.9 \\
\hline 36 & pk68 & pk148 & $\mathrm{CF}_{3}$ & $\mathrm{~F}$ & 0 & $\mathrm{Br}$ & $\mathrm{NA}^{*}$ & NA* \\
\hline 37 & pk73 & pk153 & $\mathrm{CH}_{3} \mathrm{O}$ & $\mathrm{CH}_{3} \mathrm{O}$ & 0 & $\mathrm{H}$ & -9.1 & -7 \\
\hline 38 & pk74 & pk154 & $\mathrm{CH}_{3} \mathrm{O}$ & $\mathrm{CH}_{3} \mathrm{O}$ & 0 & $\mathrm{~F}$ & -9.5 & -6.7 \\
\hline 39 & pk75 & pk155 & $\mathrm{CH}_{3} \mathrm{O}$ & $\mathrm{CH}_{3} \mathrm{O}$ & 0 & $\mathrm{Cl}$ & -9.5 & -6.2 \\
\hline 40 & pk76 & pk156 & $\mathrm{CH}_{3} \mathrm{O}$ & $\mathrm{CH}_{3} \mathrm{O}$ & 0 & $\mathrm{Br}$ & $\mathrm{NA}^{*}$ & $\mathrm{NA}^{*}$ \\
\hline 41 & & & $R$-Bic & & & & -10.9 & \\
\hline
\end{tabular}

*NA-no result

Table 2: Designed ligands of triazole derivatives (Series 2)

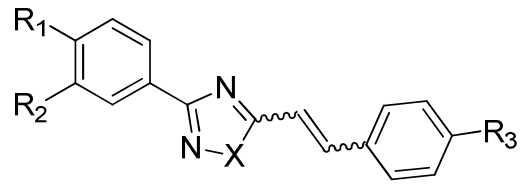

\begin{tabular}{|c|c|c|c|c|c|c|c|c|}
\hline \multirow[t]{2}{*}{ Entry } & \multicolumn{2}{|l|}{ Code } & \multirow[t]{2}{*}{$\mathbf{R}_{1}$} & \multirow[t]{2}{*}{$\mathbf{R}_{2}$} & \multirow[t]{2}{*}{$\mathbf{X}$} & \multirow[t]{2}{*}{$\mathbf{R}_{\mathbf{3}}$} & \multicolumn{2}{|c|}{ Binding affinity (Kcal/mol) } \\
\hline & cis & trans & & & & & cis & trans \\
\hline 1 & pk5 & pk85 & $\mathrm{H}$ & $\mathrm{H}$ & $\mathrm{NH}$ & $\mathrm{H}$ & -9 & -7.9 \\
\hline 2 & pk6 & pk86 & $\mathrm{H}$ & $\mathrm{H}$ & $\mathrm{NH}$ & $\mathrm{F}$ & -9.3 & -8.1 \\
\hline 3 & pk7 & pk87 & $\mathrm{H}$ & $\mathrm{H}$ & $\mathrm{NH}$ & $\mathrm{Cl}$ & -9.1 & -6.8 \\
\hline 4 & pk8 & pk88 & $\mathrm{H}$ & $\mathrm{H}$ & $\mathrm{NH}$ & $\mathrm{Br}$ & $\mathrm{NA}^{*}$ & $\mathrm{NA}^{*}$ \\
\hline 5 & pk13 & pk93 & $\mathrm{F}$ & $\mathrm{Cl}$ & $\mathrm{NH}$ & $\mathrm{H}$ & -9.8 & -8.4 \\
\hline 6 & pk14 & pk94 & $\mathrm{F}$ & $\mathrm{Cl}$ & $\mathrm{NH}$ & $\mathrm{F}$ & -10.3 & -7.8 \\
\hline 7 & pk15 & pk95 & $\mathrm{F}$ & $\mathrm{Cl}$ & $\mathrm{NH}$ & $\mathrm{Cl}$ & -10.3 & -6.7 \\
\hline 8 & pk16 & pk96 & $\mathrm{F}$ & $\mathrm{Cl}$ & $\mathrm{NH}$ & $\mathrm{Br}$ & $\mathrm{NA}^{*}$ & $\mathrm{NA}^{*}$ \\
\hline 9 & pk21 & pk97 & $\mathrm{Cl}$ & $\mathrm{F}$ & $\mathrm{NH}$ & $\mathrm{H}$ & -9.8 & -6 \\
\hline 10 & pk22 & pk98 & $\mathrm{Cl}$ & $\mathrm{F}$ & $\mathrm{NH}$ & $\mathrm{F}$ & $\mathrm{NA}^{*}$ & -7.8 \\
\hline 11 & pk23 & pk99 & $\mathrm{Cl}$ & $\mathrm{F}$ & $\mathrm{NH}$ & $\mathrm{Cl}$ & -10.2 & -6.8 \\
\hline 12 & pk24 & pk100 & $\mathrm{Cl}$ & $\mathrm{F}$ & $\mathrm{NH}$ & $\mathrm{Br}$ & -10.1 & $\mathrm{NA}^{*}$ \\
\hline 13 & pk29 & pk109 & $\mathrm{Cl}$ & $\mathrm{CN}$ & $\mathrm{NH}$ & $\mathrm{H}$ & -10.2 & -8.5 \\
\hline 14 & pk30 & pk110 & $\mathrm{Cl}$ & $\mathrm{CN}$ & $\mathrm{NH}$ & $\mathrm{F}$ & -10.8 & -7.5 \\
\hline 15 & pk31 & pk111 & $\mathrm{Cl}$ & $\mathrm{CN}$ & $\mathrm{NH}$ & $\mathrm{Cl}$ & -10.7 & -6.5 \\
\hline 16 & pk32 & pk112 & $\mathrm{Cl}$ & $\mathrm{CN}$ & $\mathrm{NH}$ & $\mathrm{Br}$ & $\mathrm{NA}^{*}$ & $\mathrm{NA}^{*}$ \\
\hline 17 & pk37 & pk117 & $\mathrm{Cl}$ & $\mathrm{CF}_{3}$ & $\mathrm{NH}$ & $\mathrm{H}$ & -10.8 & -8.3 \\
\hline 18 & pk38 & pk118 & $\mathrm{Cl}$ & $\mathrm{CF}_{3}$ & $\mathrm{NH}$ & $\mathrm{F}$ & -11.1 & -7.4 \\
\hline 19 & pk39 & pk119 & $\mathrm{Cl}$ & $\mathrm{CF}_{3}$ & $\mathrm{NH}$ & $\mathrm{Cl}$ & -10.6 & -6.9 \\
\hline 20 & pk40 & pk120 & $\mathrm{Cl}$ & $\mathrm{CF}_{3}$ & $\mathrm{NH}$ & $\mathrm{Br}$ & $\mathrm{NA}^{*}$ & $\mathrm{NA}^{*}$ \\
\hline 21 & pk45 & pk125 & $\mathrm{CN}$ & $\mathrm{CF}_{3}$ & $\mathrm{NH}$ & $\mathrm{H}$ & -11.3 & -8.3 \\
\hline 22 & pk46 & pk126 & $\mathrm{CN}$ & $\mathrm{CF}_{3}$ & $\mathrm{NH}$ & $\mathrm{F}$ & -11.7 & -7.2 \\
\hline 23 & pk47 & pk127 & $\mathrm{CN}$ & $\mathrm{CF}_{3}$ & $\mathrm{NH}$ & $\mathrm{Cl}$ & -11.6 & -6.5 \\
\hline 24 & pk48 & pk128 & $\mathrm{CN}$ & $\mathrm{CF}_{3}$ & $\mathrm{NH}$ & $\mathrm{Br}$ & $\mathrm{NA}^{*}$ & $\mathrm{NA}^{*}$ \\
\hline 25 & pk53 & pk133 & $\mathrm{NO}_{2}$ & $\mathrm{CF}_{3}$ & $\mathrm{NH}$ & $\mathrm{H}$ & -10.6 & -8 \\
\hline 26 & pk54 & pk134 & $\mathrm{NO}_{2}$ & $\mathrm{CF}_{3}$ & $\mathrm{NH}$ & $\mathrm{F}$ & -10.9 & -6.7 \\
\hline 27 & pk55 & pk135 & $\mathrm{NO}_{2}$ & $\mathrm{CF}_{3}$ & $\mathrm{NH}$ & $\mathrm{Cl}$ & -11 & -6.2 \\
\hline 28 & pk56 & pk136 & $\mathrm{NO}_{2}$ & $\mathrm{CF}_{3}$ & $\mathrm{NH}$ & $\mathrm{Br}$ & $\mathrm{NA}^{*}$ & $\mathrm{NA}^{*}$ \\
\hline 29 & pk61 & pk141 & $\mathrm{NO}_{2}$ & $\mathrm{CF}_{3}$ & $\mathrm{NH}$ & $\mathrm{H}$ & $\mathrm{NA}^{*}$ & -7.5 \\
\hline 30 & pk62 & pk142 & $\mathrm{NO}_{2}$ & $\mathrm{CF}_{3}$ & $\mathrm{NH}$ & $\mathrm{F}$ & -10.3 & -6.4 \\
\hline 31 & pk63 & pk143 & $\mathrm{NO}_{2}$ & $\mathrm{CF}_{3}$ & $\mathrm{NH}$ & $\mathrm{Cl}$ & -10.1 & -5.9 \\
\hline 32 & pk64 & pk144 & $\mathrm{NO}_{2}$ & $\mathrm{CF}_{3}$ & $\mathrm{NH}$ & $\mathrm{Br}$ & $\mathrm{NA}^{*}$ & $\mathrm{NA}^{*}$ \\
\hline 33 & pk69 & pk149 & $\mathrm{CF}_{3}$ & $\mathrm{~F}$ & $\mathrm{NH}$ & $\mathrm{H}$ & -10.2 & -7.5 \\
\hline 34 & pk70 & pk150 & $\mathrm{CF}_{3}$ & $\mathrm{~F}$ & $\mathrm{NH}$ & $\mathrm{F}$ & -10.8 & -6.3 \\
\hline 35 & pk71 & pk151 & $\mathrm{CF}_{3}$ & $\mathrm{~F}$ & $\mathrm{NH}$ & $\mathrm{Cl}$ & -10.5 & -5.9 \\
\hline 36 & pk72 & pk152 & $\mathrm{CF}_{3}$ & $\mathrm{~F}$ & $\mathrm{NH}$ & $\mathrm{Br}$ & $\mathrm{NA}^{*}$ & $\mathrm{NA}^{*}$ \\
\hline 37 & pk77 & pk157 & $\mathrm{CH}_{3} \mathrm{O}$ & $\mathrm{CH}_{3} \mathrm{O}$ & $\mathrm{NH}$ & $\mathrm{H}$ & -9.1 & -6.8 \\
\hline 38 & pk78 & pk158 & $\mathrm{CH}_{3} \mathrm{O}$ & $\mathrm{CH}_{3} \mathrm{O}$ & $\mathrm{NH}$ & $\mathrm{F}$ & -9.4 & -6.4 \\
\hline 39 & pk79 & pk159 & $\mathrm{CH}_{3} \mathrm{O}$ & $\mathrm{CH}_{3} \mathrm{O}$ & $\mathrm{NH}$ & $\mathrm{Cl}$ & -9.4 & -5.9 \\
\hline 40 & pk80 & pk160 & $\mathrm{CH}_{3} \mathrm{O}$ & $\mathrm{CH}_{3} \mathrm{O}$ & $\mathrm{NH}$ & $\mathrm{Br}$ & $\mathrm{NA}^{*}$ & $\mathrm{NA}^{*}$ \\
\hline 41 & & & $R$-Bica & & & & -10.9 & \\
\hline
\end{tabular}

*NA-no result 
The results obtained from molecular docking of designed analogs were studied and analyzed. The molecular docking analysis showed that all ligands were docked in the same ligand binding site as that of $R$-bicalutamide and showed a high binding affinity towards the androgen receptor [23]. The effect of geometrical isomers: cis and trans was studied, and cis geometrical isomers were found to be more potent as compared to trans isomers. Geometry has a profound influence on binding affinity as observed that cis isomers (adopt perfect bent conformation) are found better than their corresponding trans isomers as shown below in fig. 3 and fig. 4 . Total ten compounds from both series were shown better binding affinity than $R$-bicalutamide including $\mathrm{pk} 34, \mathrm{pk} 41, \mathrm{pk} 42, \mathrm{pk} 43, \mathrm{pk} 50$ from oxadiazole series in table 1 , entries 18, 21,22,23,26 respectively and pk38, pk45, pk46, pk47, pk55 from triazole series are in table 2, entries $18,21,22,23,27$ respectively. Among these pk42 and pk46 were studied in-depth which showed best binding affinity to the androgen receptor. The cis-isomers were found better than their trans-isomer.

The study of most potent compounds also suggests the effect of substituents on both ring; we observed that electron withdrawing functional groups such as $\mathrm{CF}_{3}, \mathrm{NO}_{2}$ and $\mathrm{CN}$ are found better than electron donating functional groups like $\mathrm{CH}_{3}, \mathrm{OCH}_{3}$ on ring $\mathrm{A}$ whereas halogen particularly fluoro found better on ring "B".

The close contacts have shown for the most potent compounds pk42 and pk46 from both classes of designed ligands. The ribbon structure of a protein is depicting the docked conformation of ligand onto the active site of protein as shown in fig. 5 and fig. 6.
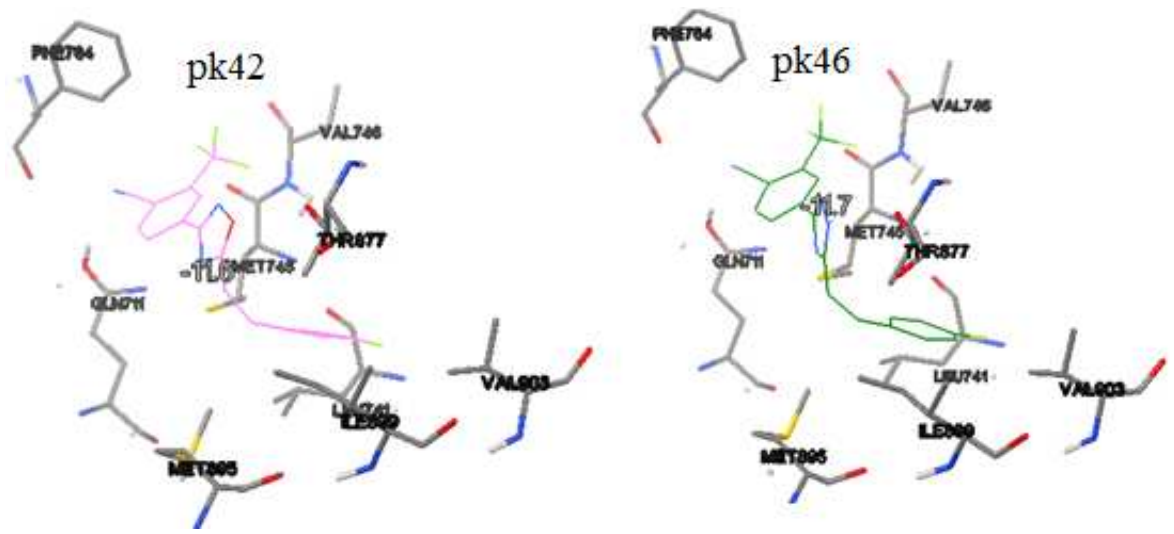

Fig. 3: Overlay of close contacts of cis isomers: (pk 42 in magenta color and pk46 in green color) with neighboring amino acid residues

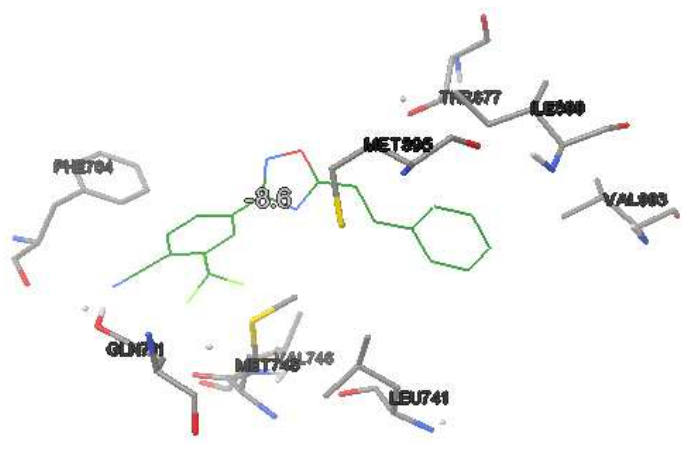

Fig. 4: Overlay of close contacts of trans isomers: (pk122) with neighboring amino acid residues

An in-depth analysis of the docked conformation onto the active site of protein, showed following interactions:

Ring A: $\mathrm{CF}_{3}$ from hydrogen bonding with Gln711, Met745 and Thr677 residues whereas CN situated in a hydrophobic region with Phe764, Val746 amino acid residues (fig. 5).

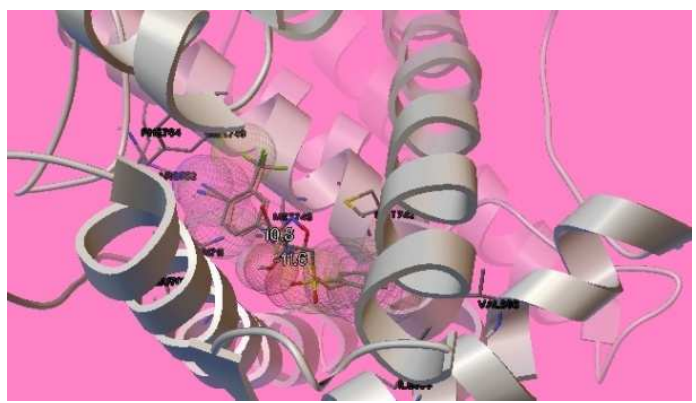

Fig. 5: Visualization of active binding sites of protein with bound ligand pk42 (oxazole) and 46 (triazole)

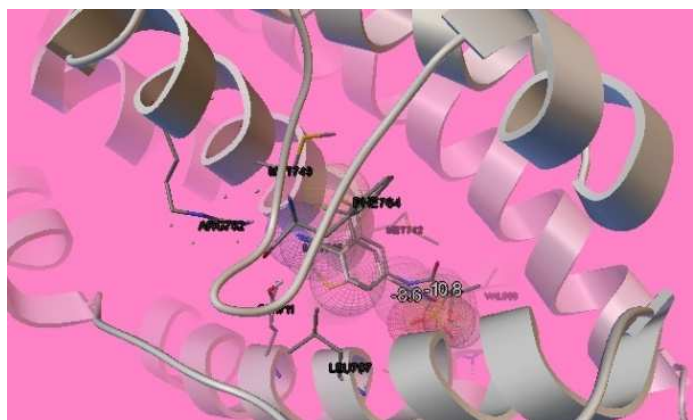

Fig. 6: Visualization of active binding sites of protein with bound ligand pk122

Ring B: adopts bent conformation and disrupts AF2 region by interacting with Leu741, Val 903.

These interactions increase the binding affinity of the ligands and suggesting for optimal electron withdrawing function groups as $\mathrm{CF}_{3}$, $\mathrm{CN}$ on ring $\mathrm{A}$ and $\mathrm{F}$ at ring $\mathrm{B}$, also the cis conformation gives the bent structure for better fitting to the binding pocket of AR.

\section{CONCLUSION}

Progression of prostate cancer occurs due to the overexpression of androgen receptor. Though it is not limited to only prostate gland it can metastasize beyond the prostate gland also and start affecting another part of the body at that stage it becomes more complicated to treat. There are several ways to cure the prostate cancer but most commonly used is chemotherapy which mainly involves two classes of drugs in treatment that are steroidal based therapy and nonsteroidal based therapy. But due to the drawbacks in steroidal derivatives, non-steroidal therapy is preferred. Nonsteroidal antiandrogens also have limited application due to resistance and severe toxicity. Herein we design the novel oxadiazole and triazole, by hoping to overcome these limitations. 160 compounds were designed and studied by molecular docking through software 
AutoDock Vina. Oxadiazoles and triazoles are found to be potent as androgen receptor modulator. The potency is being affected by the geometry of these novel compounds. Cis isomers showed better binding affinity than the trans isomers. Among these compounds, ten most feasible and potent derivatives were identified. The potent compounds which showed better binding affinity than $R$ bicalutamide like pk24 and 46 were further analyzed for their interactions. The conformational effect also found significant in binding to the androgen receptor. Further investigations on these novel agents will provide the promising tool for new drug development to treat the prostate cancer.

\section{ACKNOWLEDGEMENT}

The authors are grateful to SERB-Department of Science and Technology (DST) Govt of India for research funding under Young Scientist Scheme.

\section{CONFLICTS OF INTERESTS}

Declared none

\section{REFERENCES}

1. Jemal A, Thomas A, Murray T, Thun M. Cancer statistics. CA Cancer J Clin 2002;52:23.

2. Eden T. Aetiology of childhood leukaemia. Cancer Treat Rev 2014;36:286-97.

3. American Cancer Society. Cancer Facts and fig. 2014. Atlanta: American Cancer Society; 2014.

4. Jain S, Saxena S, Kumar A. Epidemiology of prostate cancer in India. Meta Gene 2014;2:596-605.

5. Brawer MK. Testosterone replacement in men with andropause: an overview. Rev Urol 2004;6:S9-S15.

6. Heinlein CA, Chang C. Androgen receptor in prostate cancer. Endocr Rev 2004;25:276-308.

7. Shang $Y$, Myers $M$, Brown $M$. Formation of the androgen receptor transcription complex. Mol Cell 2002;9:601-10.

8. Wang Q, Carroll JS, Brown M. Spatial and temporal recruitment of androgen receptor and its coactivators involve chromosomal looping and polymerase tracking. Mol Cell 2005;19:631-42.

9. Burger A. Abraham DJ. Burger's medicinal chemistry and drug discovery. 6th ed. Wiley: Hoboken(NJ); 2003.

10. Foye WO, Williams DA, Lemke TL. Foye's principles of medicinal chemistry. 5th ed. Lippincott Williams and Wilkins: Philadelphia (PA); 2002.

11. Singh SM, Gauthier S, Labrie F. Androgen receptor antagonists (antiandrogens): structure-activity relationships. Curr Med Chem 2000;7:211-47.

12. Goodman LS, Hardman JG, Limbird LE, Gilman AG. Goodman and Gilman's the pharmacological basis of therapeutics. 10th ed. McGraw-Hill Medical Pub. Division (NY); 2001.

13. Huggins C, Stevens R, Hodges CV. The effect of castration on advanced carcinoma of the prostate gland. Arch Surg 1947;43:209-23.

14. Westin P, Stattin P, Damber JE, Bergh A. Castration therapy rapidly induces apoptosis in a minority and decreases cell proliferation in a majority of human prostatic tumors. Am J Pathol 1995;146:1368-75.

15. Oettel M. Testosterone metabolism, dose-response relationships and receptor polymorphisms: selected pharmacological/ toxicological considerations on benefits versus risks of testosterone therapy in men. Aging Male 2003;6:230-56.

16. Migeon BR, Brown TR, Axelman J, Migeon CJ. Studies of the locus for androgen receptor: localization on the human $\mathrm{X}$ chromosome and evidence for homology with the Tfm locus in the mouse. Proc Natl Acad Sci USA 1981;78:6339-43.

17. Lubahn DB, Joseph DR, Sullivan PM, Willard HF, French FS, Wilson EM. Cloning of human androgen receptor complementary DNA and localization to the X chromosome. Science 1988;240:327-30.

18. Chang CS, Kokontis J, Liao ST. Structural analysis of complementary DNA and amino acid sequences of human and rat androgen receptors. Proc Natl Acad Sci USA 1988;85:7211-5.

19. Lubahn DB, Joseph DR, Sar M, Tan J, Higgs HN, Larson RE, et al. The human androgen receptor: complementary deoxyribonucleic acid cloning, sequence analysis and gene expression in prostate. Mol Endocrinol 1988;2:1265-75.

20. Trapman J, Klaassen P, Kuiper GG, van der Korput JA, Faber PW, van Rooij HC, et al. Cloning, structure and expression of a cDNA encoding the human androgen receptor. Biochem Biophys Res Commun 1988;153:241-8.

21. McEwan I. Molecular mechanisms of androgen receptormediated gene regulation: structure-function analysis of the AF-1 domain. J Endocr Relat Cancer 2004;11:281-93.

22. Chawnshang C. Androgens and androgen receptor: mechanisms functions, and clinical applications. Kluwer Academic Publishers: Boston (MA); 2002.

23. Bohl CE, Gao W, Miller DD, Bell CE, Dalton JT. Structural basis for antagonism and resistance of bicalutamide in prostate cancer. Proc Natl Acad Sci 2005;102:6201-5.

24. Marhefka CA, Moore BM, Bishop TC, Kirkovsky L, Mukherjee A, Dalton JT, et al. Homology modeling using multiple molecular dynamics simulations and docking studies of the human androgen receptor ligand-binding domain bound to testosterone and nonsteroidal ligands. J Med Chem 2001;44:1729-40.

25. Zhou ZX, Wong CI, Sar M, Wilson EM. The androgen receptor: an overview. Recent Prog Horm Res 1994;49:249-74.

26. Myers EW, Miller W. Approximate matching of regular expressions. Bull Math Biol 1989;51:5-37.

27. Pratt WB, Toft DO. Steroid receptor interactions with heat shock protein and immunophilin chaperones. Endocr Rev 1997;18:306-60.

28. Heinlein CA, Chang C. Androgen receptor (AR) coregulators: an overview. Endocr Rev 2002;23:175-200.

29. Shang $Y$, Myers $M$, Brown M. Formation of the androgen receptor transcription complex. Mol Cell 2002;9:601-10.

30. Matias PM, Donner P, Coelho R, Thomaz M, Peixoto C, Macedo S, et al. Structural evidence for ligand specificity in the binding domain of the human androgen receptor. Implications for pathogenic gene mutations. J Biol Chem 2000;275:26164-71.

31. He B, Minges JT, Lee LW, Wilson EM. The FXXLF motif mediates androgen receptor-specific interactions with coregulators. J Biol Chem 2002;277:10226-35.

32. Wurtz JM, Bourguet W, Renaud JP, Vivat V, Chambon P, Moras $\mathrm{D}$, et al. A canonical structure for the ligand-binding domain of nuclear receptors. Nat Struct Biol 1996;3:87-94.

33. Brzozowski AM, Pike AC, Dauter Z, Hubbard RE, Bonn T, Engstrom 0, et al. Molecular basis of agonism and antagonism in the estrogen receptor. Nature 1997;389:753-8.

34. Heery DM, Kalkhoven E, Hoare S, Parker MG. A signature motif in transcriptional co-activators mediates binding to nuclear receptors. Nature 1997;387:733-6.

35. Bourguet W, Germain P, Gronemeyer H. Nuclear receptor ligand-binding domains: three-dimensional structures, molecular interactions, and pharmacological implications. Trends Pharmacol Sci 2000;21:381-8.

36. Hur E, Pfaff SJ, Payne ES, Gron H, Buehrer BM, Fletterick RJ. Recognition and accommodation at the androgen receptor coactivator binding interface. J PLoS Biol 2004;2:E274.

37. Sathya G, Chang CY, Kazmin D, Cook CE, McDonnell DP. Pharmacological uncoupling of androgen receptor-mediated prostate cancer cell proliferation and prostate-specific antigen secretion. Cancer Res 2003;63:8029-36.

38. He B, Gampe RT, Jr Kole AJ, Hnat AT, Stanley TB, An G, et al. Structural basis for androgen receptor interdomain and coactivator interactions suggests a transition in nuclear receptor activation function dominance. Mol Cell 2004;16:425-38.

39. Warnmark A, Treuter E, Gustafsson JA, Hubbard RE, Brzozowski AM, Pike AC. Interaction of transcriptional intermediary factor 2 nuclear receptor box peptides with the coactivator binding site of estrogen receptor alpha. J Biol Chem 2002;277:21862-8.

40. Chang CY, McDonnell DP. Androgen receptor-cofactor interactions as targets for new drug discovery. Trends Pharmacol Sci 2005;26:225-8.

41. Langley E, Kemppainen JA, Wilson EM. Evidence for antiparallel orientation of the ligand-activated human androgen receptor dimer. J Biol Chem 1995;270:29983-90. 
42. Khatik GL, Kaur J, Kumar V, Tikoo K, Venugopalan P, Nair VA. Aldol derivatives of Thioxoimidazolidinones as potential antiprostate cancer agents. Eur J Med Chem 2011;46:3291-301.

43. Khatik GL, Kaur J, Kumar V, Tikoo K, Nair VA. 1,2,4-Oxadiazoles: a new class of anti-prostate cancer agents. Bioorg Med Chem Lett 2012;22:1912-6.

44. Kumar V, Rachamalla M, Nandekar P, Khatik GL, Sangamwar AT, Tikoo K, et al. Design and synthesis of optically pure 3-Aryl6-methyl-2-thioxotetrahydropyrimidin- $4(1 \mathrm{H})$-ones as antiprostate cancer agents. RSC Adv 2014;4:37868-77.

45. Kaur P, Khatik GL. Advancements in non-steroidal antiandrogens as potential therapeutic agents for the treatment of prostate cancer. Mini Rev Med Chem 2016;16:531-46.

46. Chaurasiya S, Kaur P, Nayak SK, Khatik GL. Virtual screening for identification of novel potent EGFR inhibitors through Autodock Vina molecular modeling software. J Chem Pharm Res 2016;8:353-60.

47. Shruthy VS, Shakkeela Y. In silico design, docking, synthesis and evaluation of thiazole Schiff bases. Int J Pharm Pharm Sci $2014 ; 6: 271-5$
48. Muthukala B, Kanakarajan S, Kamalanathan A. In silico docking of Quercetin compound against the Hela cell line proteins. Int J Curr Pharm Res 2015; 7:13-6.

49. Munusami P, Vasavi C, Divya G. Molecular docking studies on flavonoid compounds: an insight into aromatase inhibitors. Int J Pharm Pharm Sci 2014;6:141-8.

50. Kalita JM, Ghosh SK, Sahu S, Dutta M. A statistical analysis to find out an appropriate docking method. Asian J Pharm Clin Res 2015;7:158-60.

51. Trott 0 , Olson AJ. AutoDock vina: improving the speed and accuracy of docking with a new scoring function, efficient optimization, and multithreading. J Comput Chem 2010;31:455-61.

52. Energy minimizations were performed MM2 Interface program on ChemBio3D Ultra 12.0, and structures were drawn by ChemBioDrwa Ultra 12.0 (Cambridge Soft); 1985.

\section{How to cite this article}

- Paranjeet Kaur, Gopal L Khatik. Identification of novel 5-styryl1,2,4-oxadiazole/Triazole derivatives as the potential antiandrogens through molecular docking study. Int J Pharm Pharm Sci 2016;8(10):72-77. 